\title{
Tighina-Bender Fortress - (Re)Inventing a Museum
}

\author{
Sergiu MUSTEAȚĂ \\ Ion Creangă State Pedagogical University, 1 Ion Creangă St., 2069, Chișinău, MD; \\ sergmusteata@gmail.com
}

\begin{abstract}
This article discusses the case of the transformation of the Tighina-Bender fortress in a historic museum and tourist attraction site. The fortress is one of the most important medieval fortifications in Eastern Europe and is a national monument registered in the State Register of Protected Monuments of the Republic of Moldova. Paradoxically, but the fortress has not benefited from serious historic and archaeological research so far. It must be because during the Soviet era the fortress was a military base and it was closed to the public. Its recent transformation into a museum, the launch of a rehabilitation project, and ensured access inside this fortification inspire us for the possibility of transforming this site into one of the most attractive tourist places in the Republic of Moldova. But for better interpretation and presentation is strictly necessary to understand the history of the place, its role from regional and European perspectives, the relation of historic place with the local community, etc. (Re)inventing a museum needs, in, first of all, a vision and, secondly, a strategy of museum sustainable development.
\end{abstract}

Keywords: Tighina-Bender fortress; museum; heritage preservation; cultural tourism.

\section{Introduction}

Cultural Heritage has a strong relationship with History, because history is the main academic discipline that explains the past, while heritage is based on the results of human activities in the past. In this context, Heritage is linked with Identity too, because heritage represents the roots of origins and particularities of each community. During the last two centuries museums have taken an important role in presenting history, heritage, and identity issues - „to recreate the past in an idiom accessible to present" (Hein, 2000, p. 31). But because of political interest in various heritage, history, and identity issues, museums quite often are in difficult positions.

„Museums are man-made institutions in service of men” (Wittlin, 2004, p. 45) but how to remain relevant for society when politics are so much involved in museum affairs? Traditionally, it is considered that museums are playing an educational role. But in some circumstances, a museum could be a provocateur too. Heritage, like history, during the last centuries, was used improperly and abused often (Fero, 1981; Graham, Ashworth, \& Tunbridge, 2005). In these circumstances, a museum usually is a place of confronting past and present, history and politics, „a space where knowledge is transformed, negotiated, and visualized in terms of regimes of power and knowledge" (Koksal, 2014, p. 233).

Today, we are living in a contradictory time too. That's why museums have to be comprehensive - as centers of research and innovation, to deliver experiences, as catalysts for creativity, and new educational models, as community institutions and as forums that bring people together and help them to understand the past, to support democratic values, human rights, tolerance, and sustainable peace education (Anderson, 2004, pp. 1-7). Museums are increasingly more active participants in their communities, involved in fighting injustice (Sandell, 2007) and acting for social change (Knell, 2019). They are not passive institutions, but rather participatory organizations (Simon, 2010). Nevertheless, not all museums are activist museums, or the public does not perceive them as such (Zbuchea, Romanelli, \& Bira, 2021). Still, to some extent, most museums seem to be aware of their new responsibilities and the expectation that society

How to cite

Musteață, S. (2021). Tighina-Bender Fortress - (Re)Inventing a Museum. Culture. Society. Economy. Politics. 1(1), 21-39. DOI 10.2478/csep-2021-0003

ISSN (online) 2810-2010

https://website.sciendo.com/publication/culture-society-economy-politics/

http://www.facultateademanagement.ro/culture-sep/ 
increasingly more have with their activity. Sometimes, the political context would push museums more in these directions and would put barriers to their activist engagement.

Therefore, a museum in the 21st century has a great and difficult mission and challenge to remain relevant for multicultural and pluralistic societies. To deconstruct old paradigms, we need to rethink the museum and, finally, reinvent the museum. In cases of the historic sites related to military events, border and conflict disputes, and other sensitive issues finding a balanced approach is not so easy, that is why in such situations those museums have to be the result of essentially compromises (Newhouse, 2006, p. 16). To reach this goal, those museums need a vision and sustainable strategy based on new museum theory and practice (Marstine, 2008).

The present paper discusses the case of the Tighina-Bender fortress which was recently opened as a museum in very specific circumstances, because the city of Bender and its surroundings are part of the territory controlled by the separatist regime of Transnistria, claiming its independence from the Republic of Moldova. The Tighina-Bender fortress, one of the most important monuments of military architecture in South-Eastern Europe, was taken under the protection of the state by the decision of the Soviet Ministers of the Moldavian SSR no. 256 of August 8, 1975 (monument of history and culture). With the obtaining of the Republic of Moldova's independence (1991) and the adoption of the Law on the protection of monuments (1993), the Tighina-Bender fortress was registered in the State Register of Monuments under no. 12 (2238) as an archaeological and architectural monument of Tighina city, a site of national importance. Although the fortress is part of the Register of Monuments protected by the state of the Republic of Moldova, the Chișinău authorities have no influence on the decisions of the separatist administration regarding the management, conservation, restoration, and use of this historic site.

Thus, the article discusses, based on the example of the Tighina-Bender fortress, several aspects of how a historic site has been used by political regimes, including the recent "reinventing museum" process.

\section{The heritage and history of the Bender fortress}

To understand and present a historic site, first of all, it is important to study its past. The Tighina-Bender fortress is a special case, from many points of view. That is why understanding the history of the fortress should be the first step in the process of transforming the site into a museum. The geographic particularities are important too because the environmental factors help us understand its strategic position, the role of fortification in the context of political, military, economic, and cultural relations, etc. The Tighina-Bender fortress is located on the right bank of the Dniester River, near a ford, which in the medieval period facilitated the faster crossing over this river. That is why the Moldovan administration established in the 15 th $\mathrm{c}$. in this area a custom fortified point.

During the 19th and the 20th centuries, several studies were published in which the issue of origin and development of the Tighina-Bender fortifications was addressed. Some historians believe that the stone fortress was built in the 12th century by the Genoese (A.I. Zașciuk, A. Nakko, and N. Iorga), P.N. Batjuškov considers that it was built by Lithuanians, and others attribute it to the Tatars (G.B. Montalbani, and G. Astvačaturov). V. Voițehovschi, compared with other scholars, supports the idea of Moldovan origins of the Tighina stone fortress, which probably was built by Moldovan rulers at the end of the 14th c. and after the occupation by the Ottoman Empire in 1538 the fortress was extended. Originally the fortress was built from soil and wood, and after it was conquered by the Turks in 1538, and the stone citadel was built (Șt. Ciobanu, C.C. Giurescu, D. Poștarencu, I. Chirtoagă, and M. Șlapac) (Șlapac, 2004, pp. 110-114, 146$152 ; 2016$, pp. 127-155; 2020, pp. 354-363). 
The first documentary attestation of Tighina (Tiaghianiachiaciu) is from the time of the ruler Alexandru the Good, in 1408 when the existence of a customs point in the ford area is mentioned. Some documents from the 15th century mention Tighina, in the context of trade relations, several times - 1434 (Teghenicheciu), 1452 (Teghini), 1456 (Tighinichiaciou) (Gonța, 1998, pp. 108). Unfortunately, these documents do not give us many details about the Tighina fortifications. D. Cantemir, in his great work the Description of Moldova, mentioned Tighina as an important fortress. However, D. Cantemir did not mention the sources which show what the fortress had been like before its conquest in 1538 by the Turks. Perhaps, the Moldovan ruler came to this conclusion based on the realities of the Turkish fortress from the beginning of the 18th century, which was recovered from the Turks several times by the army of Moldova, for short periods.

In 1538 Soliman I (1520-1566) occupied most of Moldova. The Moldo-Polish Chronicle referring to these events mentions that Turks occupied „a Moldavian castle, Tighina” (Sava et al., 2014). In this context, the castle and the surroundings of Tighina were included in the Akkerman Sangea, and in 1566 Bender Sangea was created. The Turks also change the name of Tighina to Bender, which means "hardened transient" in Turkish. The year of the conquest appears on the tarih, the inscription from the entrance to the citadel. The Turkish traveler, Evliya Celebi writes that after the conquest of Tighina, the Turks built a square stone fortress with two entrances, with a deep ditch only from the dry land side. E. Celebi visited Bender fortress in 1657. His writings refer to the state of the place since the middle of the 17th century, and the situation from the 16th - the first half of the 17th century, described from the sources accessible to him at that time, including the stories of the inhabitants of the fortress. The fortress was planned by the famous Turkish engineer Sinan ibn Abdulmennan, who had participated in the campaign of 1538 against Moldova. A report from 1541 mentions the Bender fortress on the Dniester. In 1593, the Polish chronicler Martin Broniowski mentions the existence of the town of Techina and the Turkish fortress not long ago built at the mouth of the Dniester.

In the year 1574, as a result of the attempt of the ruler Ioan Vodă cel Viteaz to free the country of Moldova from the Ottoman suzerainty, according to the reports of the chronicler Grigore Ureche, the Turkish sites Bender and Ackerman were burnt. The Turks recovered these fortresses, but the attacks of the Cossacks often mobilized them to strengthen their positions in the Dniester region. Another written document informs us that in 1579 the Turks built a new fort near Bender. Some historians believe that this fortification was built on the left bank of the Dniester, somewhere near the current town of Parcani. In 1583, the Poles and the Cossacks attacked the Bender fortress and burnt its suburbs. The fortress must have suffered from this attack, as repair works were certified in the spring of 1584, financially covered by Petru Șchiopul, the ruler of Moldova. At the end of 1593, the Cossacks devastate the Bender region again. From other medieval sources, it appears that the Moldovans, the Poles, and the Cossacks attacked the cities controlled by the Turks quite often. Thus, in 1595 it is attested that "the Moldovans blew everything with their mines, leaving only the citadel ...". Respectively, after each incursion and destruction, the fortress and its surroundings were renovated and supplemented with new fortification structures. For the same reasons, the number of garrisons in the fortress Bender was increased several times, which, in 1670, numbered over 500 pedestrians, knights, and artillerymen (Gonța, 1998, p. 121). 


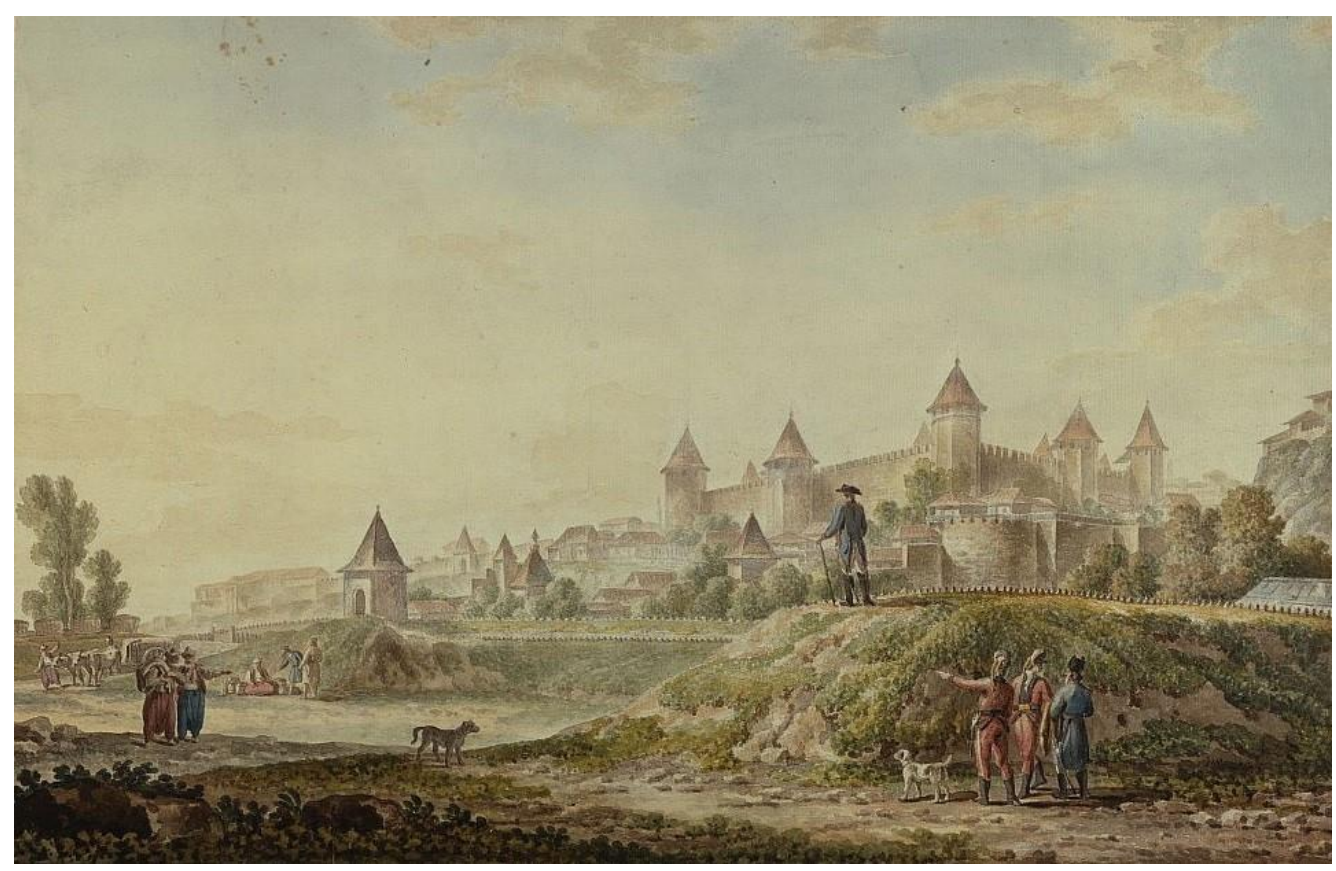

Figure 1. Bender fortress

(Painting, M. Ivanov, 1790, after Șlapac, 2016, p. 146, Fig. 116)

The Bender fortress appears quite often in the documents of the 17th - 18th centuries, due to the attacks of the Cossacks, economic relations, or some travelers who crossed the city. One of the most important changes/developments of the city of Bender is related to the change of the residence of the Turkish governor from Babadag to Bender, after the loss of Kamenetz in 1699. Ion Neculce mentions this fact "In the summer, Jufo-pasha moved from Baba saracherlic to Tighine ... That has begun to repair the fortress, to enlarge it, has worked for a few years ... ". I. Neculce also describes how the Moldovan ruler Antioh Cantemir (1705-1707), at the command of the Turks, led a lot of wood to the fortress Bender in 1706, and, in the spring of 1707, he helped with labors - "People from Walachia had come, some were digging in the ditch of the fortress, others were carrying wood... That was the year when the Tighina citadel was enlarged with the ditch built of stone and with tabs, and four large gates of stone were built ... All the burden was on the country of Moldova that carried stones and boulders, hay and wood in all years. If they needed a bag, a sieve was still in demand from Moldova". The works also continue in 1708 - "the Danube principalities and the Wallachian rulers to help strengthen the fortress of Bender". Over several decades, new construction (repair) works at Bender Fortress are attested. In the book of the ruler Constantin Mavrocordat, it is attested that the Chișinău serdar sent all the requested timber to Tighina and that the Moldovan workers worked for three months at the fortress, and the Turkish administrator from Bender demanded from the ruler of Moldova an additional amount of money (Gonța, 1998, pp. 123-124, 127).

After the failure at Poltava in the war against Russia in 1709, King Charles XII of Sweden took refuge near the Bender fortress. But after a short time, he organized his camp (Karlopolis) at Varnița, the village near Bender, where he settled until 1713, planning a new war against Russia and waiting for Ottoman aid (Denndorf, 2019). In the 1920s the Romanian administration, on a request of the Swedish government, placed a commemorative obelisk on the place of the camp of the Swedish king Charles XII at Varnița, near Bender fortress (Levinschi \& Sava, 2013, p. 389). For few decades the site is under the administration of the History of Moldova National Museum which did some archaeological investigations and restoration works (Tentiuc, Levinschi, \& Sava, 2017, p. 124). 
In 1770, during the Russian-Turkish war (1768-1774), the fortress of Bender was attacked, besieged, and finally conquered by the Russian army (Figures 1 and 2). As a result of this struggle, several sectors of the fortress suffered damage. As the Russians dug a tunnel under the earth's wave, they introduced powder barrels. After the explosion provoked on September 14, 1770, the Russian army assaulted and occupied the Bender fortress on September 15, 1770. As a result of these struggles, the fortress suffered quite a lot, and many houses in the city were burnt. Empress Catherine II, finding out about the occupation of Bender fortress, said "losing so much and receiving so little, it would have been better not to take Bender at all". But, after the Kuciuk-Kainargi (Küçük Kaynarca) Peace Treaty (1774), the fortress returns to the Turks, who had done damage to the repair works since 1770. Due to the massive destruction and the lack of sufficient resources for the repair works of the fortress, the staff of the Bender serachier passed to Ismail. In 1785, Bender is hit hard again, this time by the plague, which harmed the population in the region. The city's repair works are also attested after the RussianTurkish war of 1787-1792 when Russia extends its borders to the Dniester. For example, in 1787, the Sultan asked the ruler of Moldova repeatedly to bring the timber needed for the repair of the supports for the cannons and the repair of the fortress to Bender (Gonța, 1998, p. 129).

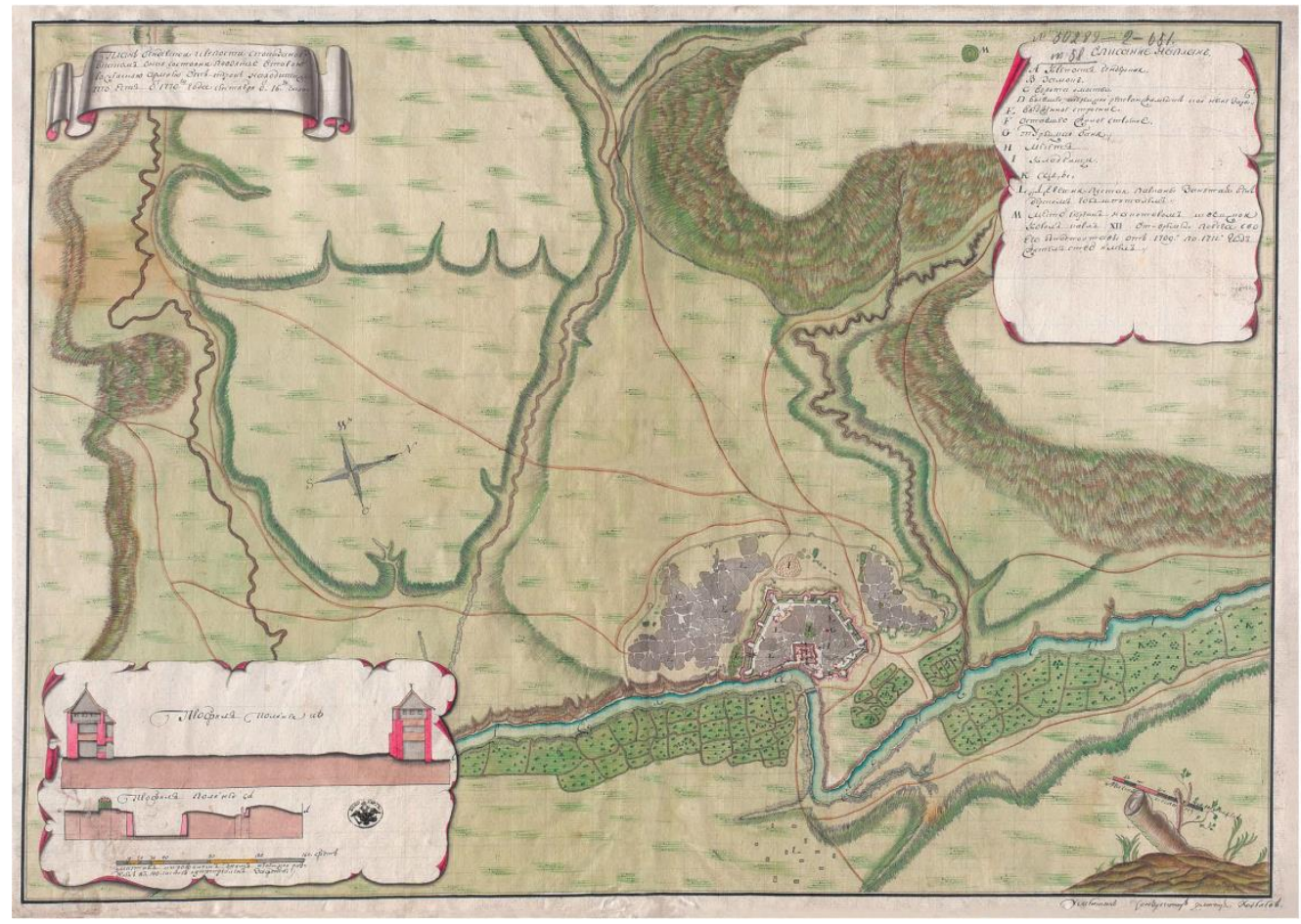

Figure 2. Map representing Bender fortress and its surroundings - 1770 (after Nesterova, 2020, Fig. 2a)

At the beginning of the 19th century, in the context of the Russian-Turkish war of 18061812, the Turks ceded the Bender fortress to the Russians, who occupied all the space between the Prut and the Dniester, later named the region of Bessarabia, by the Peace Treaty in Bucharest (1812). Thus, between 1812 and 1917, the fortress Bender was administered by the Russian administration, which placed a military garrison here. Although the fortress loses its defensive functionality, throughout the 19th century the Russian authorities operated several works to repair the stone walls and to build some buildings inside it. In the interwar period Bessarabia, and, respectively, the TighinaBender fortress were part of Romania. Romanian administration had some plans to capitalize the fortress as a historic monument but because of WWII, they were not implemented. During World War II, some sectors of the fortress suffered from aerial bombardments. 
After World War II, the Bender fortress, part of the Moldavian SSR, was transformed into a Soviet military garrison, which existed until 1991. After the dissolution of the USSR and the independence of the Republic of Moldova, the Bender fortress has been controlled by the Tiraspol administration, using it as a place of military unit dislocation. During this period, the fortress enclosures were used/adapted for the needs of the military unit, and some towers of the citadel were used as trash places.

From the brief history of the Tighina-Bender fortress mentioned above, several periods can be observed in the construction, destruction, restoration, and development of the fortifications. In one of his recent studies, based on architectural research from 2010, A. Krasnožon (2011, p.250) proposes a periodization of the defensive constructions from Bender, which refers more to the Turkish and Russian stages, which can be observed in Figure 3: the first stage (1538), the second stage (1579), the third stage (1584), the fourth stage (1617-1619), the fifth stage (October 1791 - August 1794) and the sixth stage (1820-1840). T. Nesterov considers that most of the references so far have focused largely on the Ottoman period and have not been capitalized on all historical and architectural sources concerning the Moldavian period until the conquest of the fortress by the Turks from 1538 (Nesterova, 2020). Therefore, for a better understanding of the realities of Tighina-Bender, we believe that a more complex approach, covering all historical periods, should be applied. These historical periods are related to the political regimes that dominated the region, including the Tighina-Bender fortress:
1. Moldovan period (1408-1538);
2. Ottoman period (1538-1812);
3. Russian period (1812-1917);
4. Inter-war period (1918-1940);
5. Soviet period I (1940-1941);
6. Second World War (1941-1944);
7. Soviet period II (1944-1991);
8. Transnistrian I (1991-2007);
9. Transnistrian II (2008-present).

Each political regime has left its mark, more or less pronounced though. The most pronounced period, from the point of view of the construction of the fortress and the defensive systems, is the Turkish one. But, unfortunately, the systematic research of the Tighina-Bender fortress is still missing.

\section{The heritage and archaeology of the Bender fortress}

Although the Tighina-Bender Fortress is one of the most important medieval fortifications on the Dniester, it has not benefited from systematic archaeological research so far. The fortress was the subject of small archaeological surveys in 1969, 1990, and 2019.

The first survey was conducted in the autumn of 1969 by Ion Hâncu, at the request of the director of the Ethnography Museum in Bender, A.V. Zajcev. Two sections were investigated: an area of 8,0 square meters, near the octagonal bastion of the Bender fortress and another area of $28.0 \mathrm{~m} \times 2.0 \mathrm{~m}$ near the citadel. The archaeological excavations at the Tighina-Bender fortress were reported in a short newspaper article in the early 1970s (Hynky, 1970), and the results were partly published in 1997 in a collection of studies with limited distribution (Hâncu, 1997, p. 97). Thus, little is known about these archaeological investigations. All the more, in the process of our research, we found the lack of reports on the archaeological investigations of 1969 in the archaeological archive. Also, in the article of 1997, Ion Hâncu only describes the researches near the citadel, without giving details about the area next to the octagonal bastion. In the 28,0 m long section, oriented from North to South, and 2,0 $\mathrm{m}$ wide, which 
was attached to the middle bastion of the north wall of the citadel, four large pits, the traces of a stone wall ditch, a ditch with defense wave and a deep construction, dating to the 18th-19th centuries, were discovered. The stone wall trench was discovered at a distance of $16.0 \mathrm{~m}$ from the citadel wall, parallel to the North wall. In this ditch, among other archaeological materials, a Russian coin from 1749 was discovered. The second ditch (with a defense wave) was discovered at a distance of $6.0 \mathrm{~m}$ from the wall of the citadel, being oriented in length from Northeast to Southwest, below an angle to the citadel. The ditch had a depth of $3.9 \mathrm{~m}$ from the current level of ironing and a width of $3.8 \mathrm{~m}$. At the bottom of the ditch, ceramic fragments were found, dated to the 15-16 centuries by the research author. On the western edge of the ditch, the traces of the defense wave were observed, the size of which was, in all probability, equal to the width and depth of the ditch. In the ground wave, traces of a deep construction were discovered, one of its sides being parallel to the edge of the ditch. Based on archaeological materials (mostly ceramics), the construction dated to the 15th-16th centuries. Finally, the author of the research considers that the ditch and soil wave and the dwelling remain can be attributed to the Tighina fortress (the fortress of soil and wood), which was destroyed at a certain stage of time. The ditch and the dwelling were covered with the soil from the wave. Above the leveled place, the stone citadel was built, which, from a stratigraphic point of view, intersects the traces of the fortress (soil and wood) from the 15 th to 16 th centuries (Hâncu, 1997, pp. 97-98).

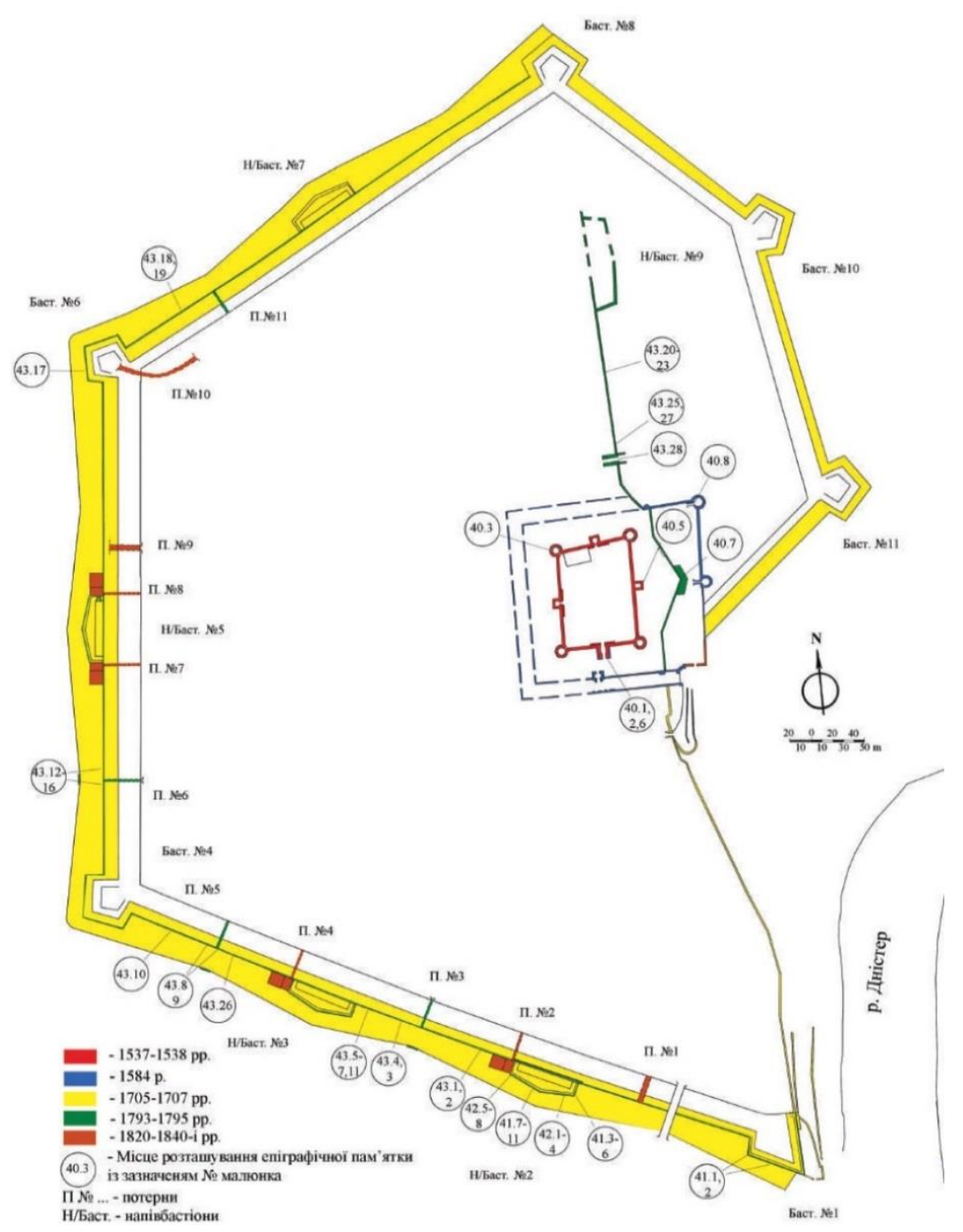

Figure 3. The general plan of the fortifications at Tighina-Bender (Krasnozhon, 2018, Fig. 36) 
Based on these findings, Ion Hâncu concluded that on the place where the stone citadel of Tighina-Bender is located, there are traces of habitation from the ancient period (Gethian culture, the Santana de Muresh-Cernjachov culture) and early medieval period (the 9th -10th centuries). During the 15th -16th centuries, this place was a soil and wood fortress with defense ditches and waves, which was most likely known as Tiaghin. Once the Turks conquered this fortress in 1538, it was burned, the place was leveled and on this area, and the stone citadel was built (Hâncu, 1997, p. 99). Among the conclusions of Ion Hâncu, there is also one related to the research perspective of the Tighina-Bender fortress, claiming that systematic and archaeological excavations on extended surfaces are needed to know the Moldovan medieval realities from Tighina. But such excavations did not follow the investigations of 1969. In all likelihood, the Soviet authorities did not accept the idea of systematic archaeological research. All the more so, the fortress was occupied by a military garrison of the Soviet Union Army. Therefore, as we can see for political reasons, the Soviet authorities used a historical monument for military purposes and did not accept the idea of adequate capitalization of a historical site, as well as archaeological research that would have solved several problems regarding the appearance and development of Tighina-Bender.

In 1990, Natalia Golitseva, from the History Museum of the Moldavian SSR, carried out archaeological research in the Southern part of the fortress Bender, in a sector of the defense fort and the wall planned to be restored. The purpose of the archaeological investigation was to investigate the traces of the defense trench, the stratigraphy of the trench filling, and the elaboration of suggestions for the restoration team. The archaeological researches were carried out at the request of the "Moldrestaurare" Combinate, responsible for the implementation of the project to restore the Bender fortress. The archaeological section was drawn perpendicular to the wall of the fortress on a surface of $3.0 \times 29.80 \mathrm{~m}$. In addition to the garbage collected over the years at the bottom of the trench, a cultural layer was also investigated, the thickness of which varies between $30.0 \mathrm{~cm}$ and $80.0 \mathrm{~cm}$. On the investigated surface traces of black holes that were related to the early phases of planning or supporting the wall of the fortress were discovered. The archaeological material uncovered during this campaign comprises ceramic fragments, fragments of pipes, iron nails, animal bones, and iron cannonballs. The discoveries date from the 18th century by the author of the archaeological report (Goliceva, 1991).

The third archaeological intervention took place in early 2019 (February 11-March 23) inside the Southeast tower of the citadel and was carried out by archaeologists from the University "T.G. Shevchenko" from Tiraspol. The authors of the research consider that this tower, and probably the entire citadel, was built by the Turks in the late 1530s of the 16th century, during Sultan Suleiman I (1520-1566). Later, the tower was consolidated and rebuilt several times. Thus, as a result of these investigations, five culturalchronological horizons were highlighted: the first represents the construction of the citadel by the Turks from 1538-1539, the second represents the reconstruction of 1584, the third relates to the renovation works of the last quarter of the 18th century, of the fourth is related to the events of 1918-1919 and the fifth represents the traces of the years 1970-1991 (Razumov, 2019).

The fourth survey was carried out in October 2019, when researchers from the "Ion Creangă" State Pedagogical University and the National Archaeological Agency conducted preventive archaeological investigations at the Tighina-Bender fortress. The survey was initiated at the request of the Italian company Studio Berlucchi, which was contracted by the UNDP Moldova to elaborate the feasibility study and the masterplan of the city of Tighina-Bender during the fifth phase of the European Union Confidence Building Measures Program (EU- CBM V), implemented by the UNDP Moldova. The preventive archaeological researches in the autumn of 2019 at the "Tighina-Bender Fortress" have pursued several main objectives: obtaining the technical data necessary to finalize the restoration solutions; unloading of the archaeological load of the archaeological heritage areas affected by the reconstruction works; the retrieval of all 
the historical-archaeological information regarding this architectural ensemble. Because of time pressure, only 32,64 square meters were excavated, divided into three sections 1,2 , and 3 (Figure 4). These excavations, even if they were in very small areas, are very important and supporting the idea of the necessity to do archaeological excavations on large scale inside and outside of the citadel and the fortress (Musteață \& Ciobanu, 2021). But this work should be done together with colleagues from other domains, such as geology, architecture, etc. Without these surveys, it is impossible to take some decisions and do some suggestions for sustainable conservation and restoration work.

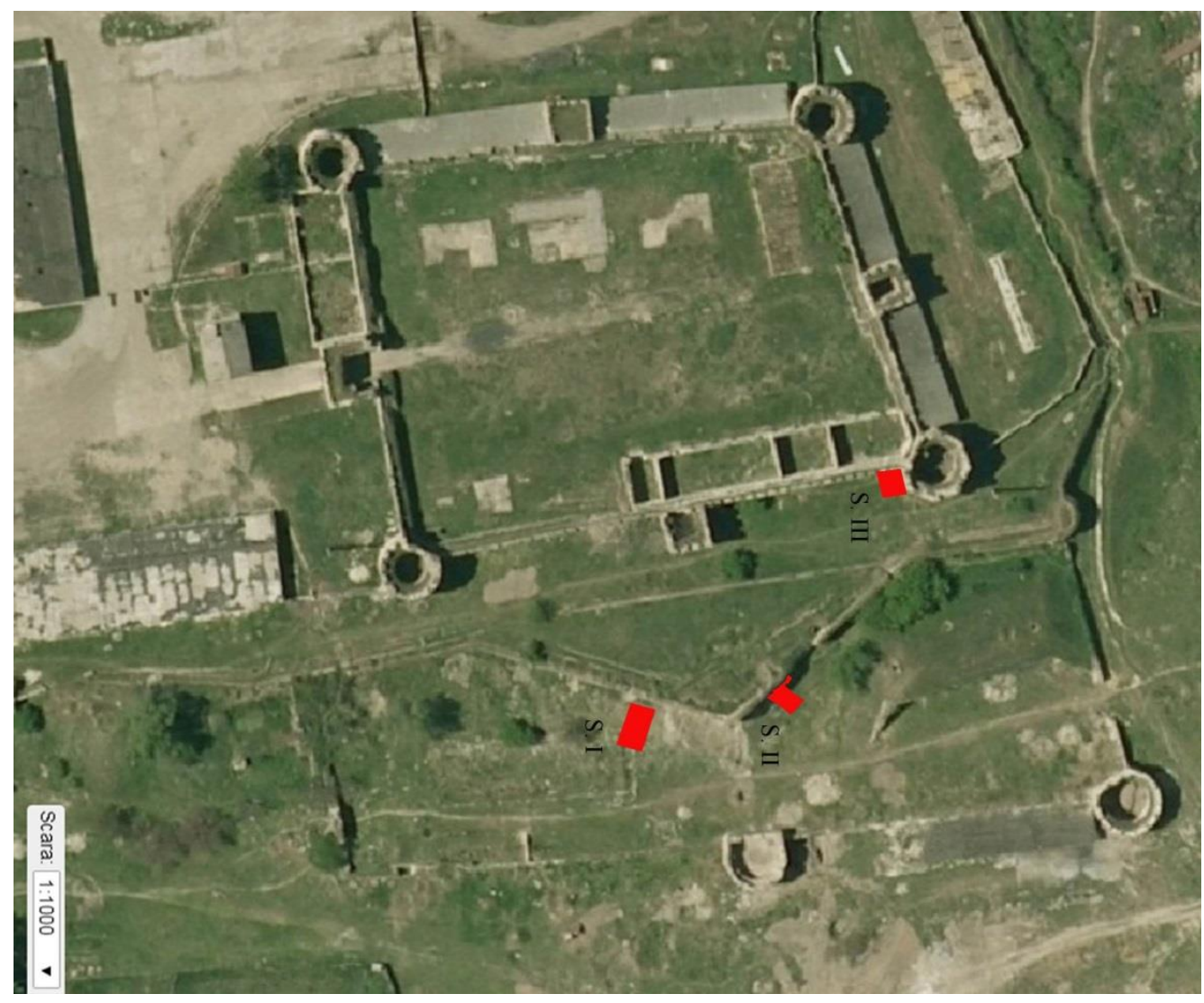

Figure 4. The plan of the Tighina-Bender citadel and the location of the archaeological sections excavated in October 2019 (done by Ion Ciobanu)

\section{Reinventing a museum}

In 2007, based on a decree by the Tiraspol separatist leader, the fortress was transformed into a museum - Benders fortress. Historical military memorial complex (https://bendery-fortress.com/en/) - and the „renovation” works began. After a long time of using the fortress as a military camp during the Soviet and post-soviet periods, the historic site looks quite bad and restoration work was extremely necessary (Figure $5)$. 


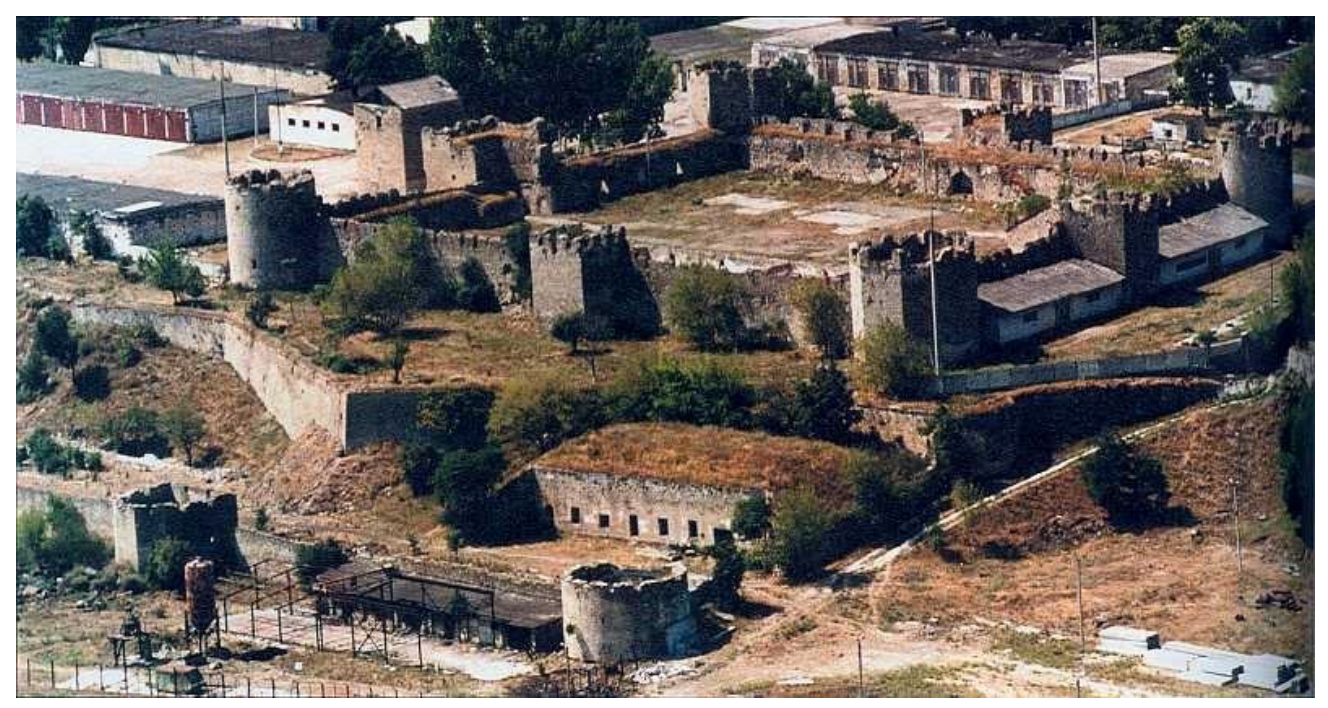

Figure 5. Tighina-Bender fortress after the departure of the military (photo M. Potârniche, source: Șlapac, 2020, p. 355, Fig. 5.84)

Although the fortress is a national monument and, according to the 1992 peace agreement, the city of Bender must be under double administration, the Tiraspol authorities did not coordinate activities with Chișinău officials. Thus, in the years 2007 2008, the first works for the arrangement of the fortress and the placement of the roofs on the fortress towers were executed. The quality of these works leaves much to be desired because they were made without a vision and a rehabilitation plan of the fortress based on the basic concepts of restoration - preserving the authenticity and integrity of the monument. The structure of the roofs, the construction materials do not largely correspond to the conservation and restoration requirements. In some cases, the dimensions of the roof are smaller than the tower, which proves that they were arranged without a well-thought-out plan (Figure 6).

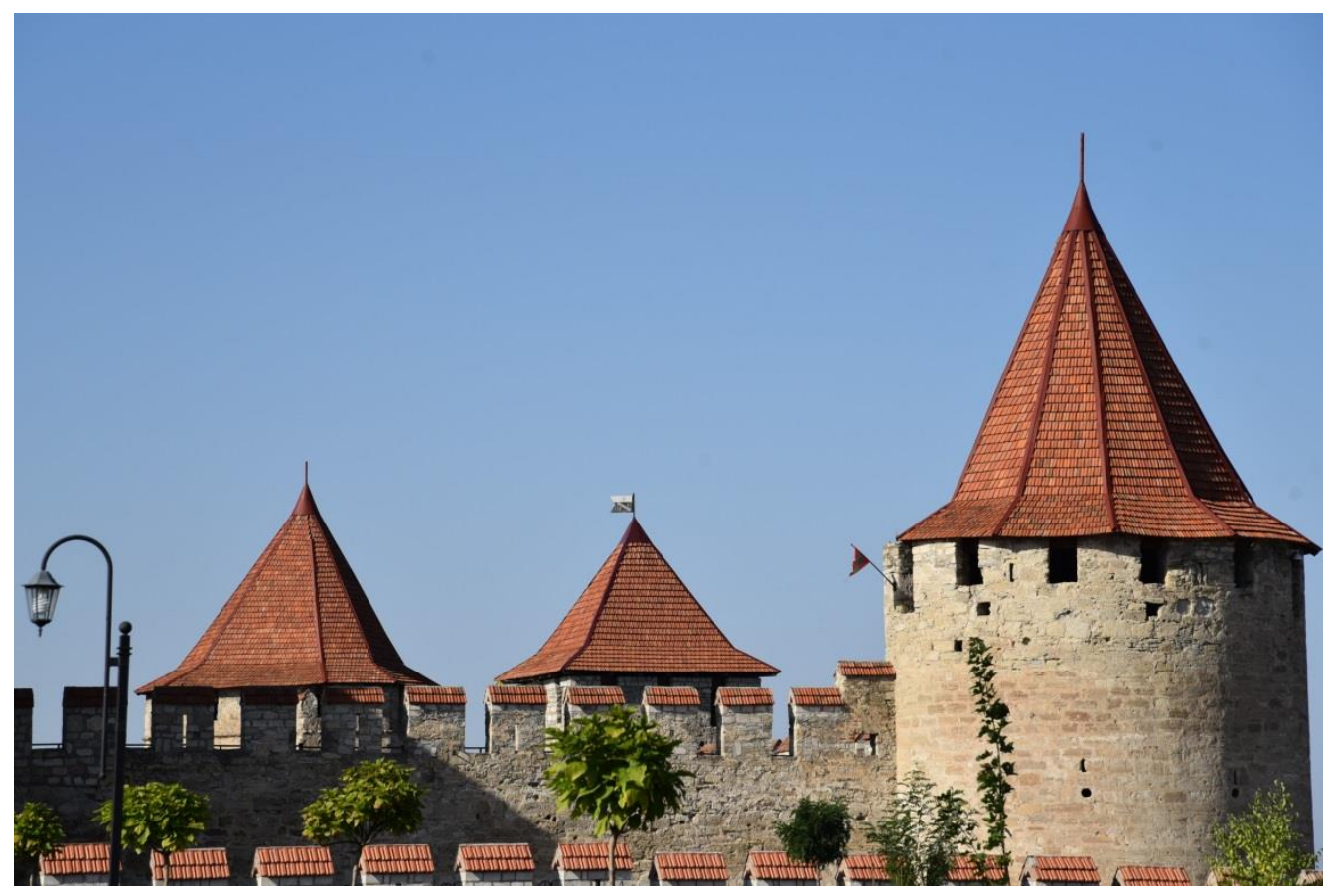

Figure 6. The Tighina-Bender towers and walls after „restoration” (author's own photo, 2019) 
Other works were carried out on the territory of the Tighina-Bender fortress, such as arranging a park and a monument dedicated to Alexander Nevsky, which has nothing in common with the history of this place or even regions (Figure 7).

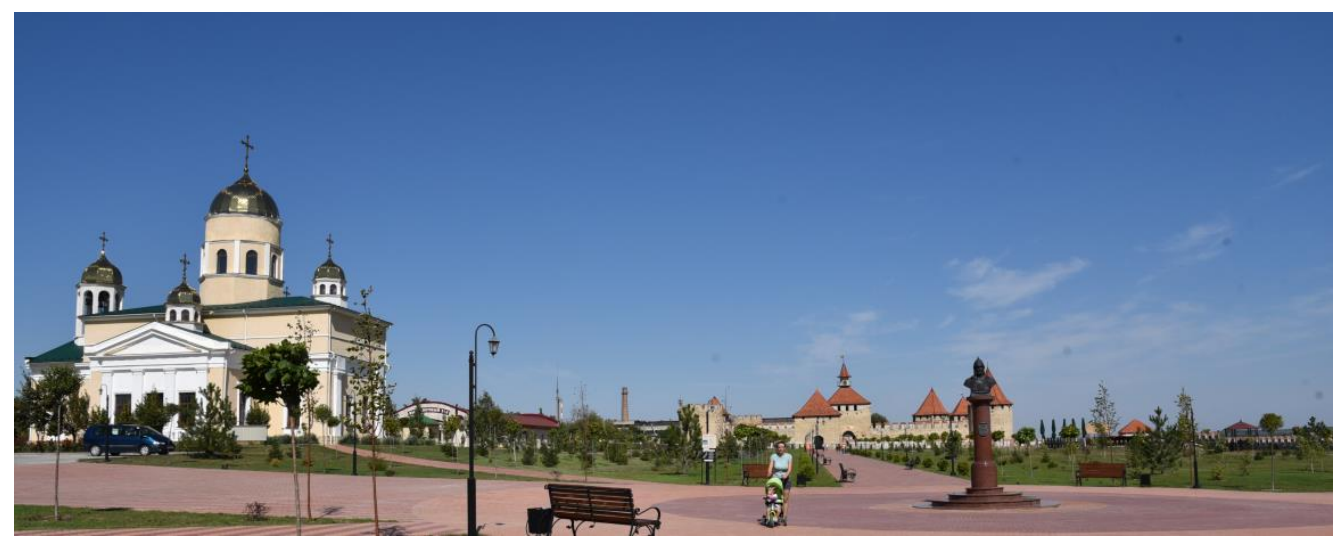

Figure 7. The Alexander Nevsky's Park, monument and military church

(author's own photo, 2019)

Probably the park and monument were done in the context of the rehabilitation of the military church Alexander Nevsky, built in 1833 but used as a cultural club during the Soviet period (http://aleksandronevskii.prihod.ru/istorija_khrama). „The story of mythologizing the figure and actions of Alexander Yaroslavich (and by no means just of him) reflects both the history and the very essence of the Russian system of power" (Lipatov, 2012, p. 93).

I will not discuss his historic role in the 13th c., but it is appropriate to know some facts which are not part of the Russian official history - for his loyalty to Mongols he became the Khan's relative, Alexander and the Khan's son Sartaq cut their hands and ritually mixed their blood, becoming brothers, he signed peace with Batu-Khan and did not fight against Golden Horde. Most of Alexander Nevsky's heroism is focused on his victory in the "grande battle" on the Neva River against Swedes in 1240. The myth of Alexander Nevsky's heroism was developed since the 15th c. associated with the founding of the Moscow state. So, during centuries Alexander Nevsky (1220-1263) was transformed into a national hero and was canonized by the Russian Orthodox Church in 1547. Empress Catherine introduced the Order of At. Alexander Nevsky as the highest decoration for military merit. During the 18-19 c. the name of A. Nevsky was used at large scale naming churches, cathedral, streets, etc. The communist regime used Alexander Nevsky's myth too in official propaganda (e.g. 1938 Sergey Einstein dedicated a victorious film to A. Nevsky; in 1942 they introduced an order of Al. Nevsky, one of highest military distinction; public monuments, etc.). Therefore, during the last centuries, the name of Alexander Nevsky was transformed into a myth, cult, and idol of the Russian people, which persists until today (Lipatov, 2012, p. 106).

The Tiraspol administration transferred without any discussions the Russian myth of Alexander Nevsky to the Tighina-Bender fortress which is totally out of the historic context of this region. An additional proof is a recent anniversary (May 15, 2021) by the Tiraspol administration of the 800th anniversary of the birth of Alexander Nevsky: „The anniversary of the birth of the commander Alexander Nevsky is a special day for the people of Bendery... (Sic!) Christians believe: Alexander Nevsky remains the defender and patron of the Russian land even after his death" (Fortress, 2021). Using the myth of Alexander Nevsky at the Tighina-Bender fortress is a case of manipulating history and subordinating history to political goals, which are totally against academic rules of presenting the past. In fact, most events organized within the Historical military memorial complex have a political connotation and are based on Russian or pro-Russian discourse, such as the events on the occasion of "Victory Day" on May 9, the festival of spiritual music dedicated to the 250th anniversary of the taking of the Bender fortress 
by the troops of PI Panin, Children's Festival "Time to Dream" (In Three Lands), etc. (https://bendery-fortress.com/en/). So, distortion of historic facts and abusing history, especially in conflict regions, are very provocative and are contrary to sustainable peace developments.

The increased attention given to the Russian period by placing the gallery of busts of Russian officers or the square and bust of Baron Munchausen is to the detriment of a balanced and correct historical approach (Figure 8), especially as they overshadow the most important period in the history of the fortress and, in fact, those who they built it the Ottoman period.

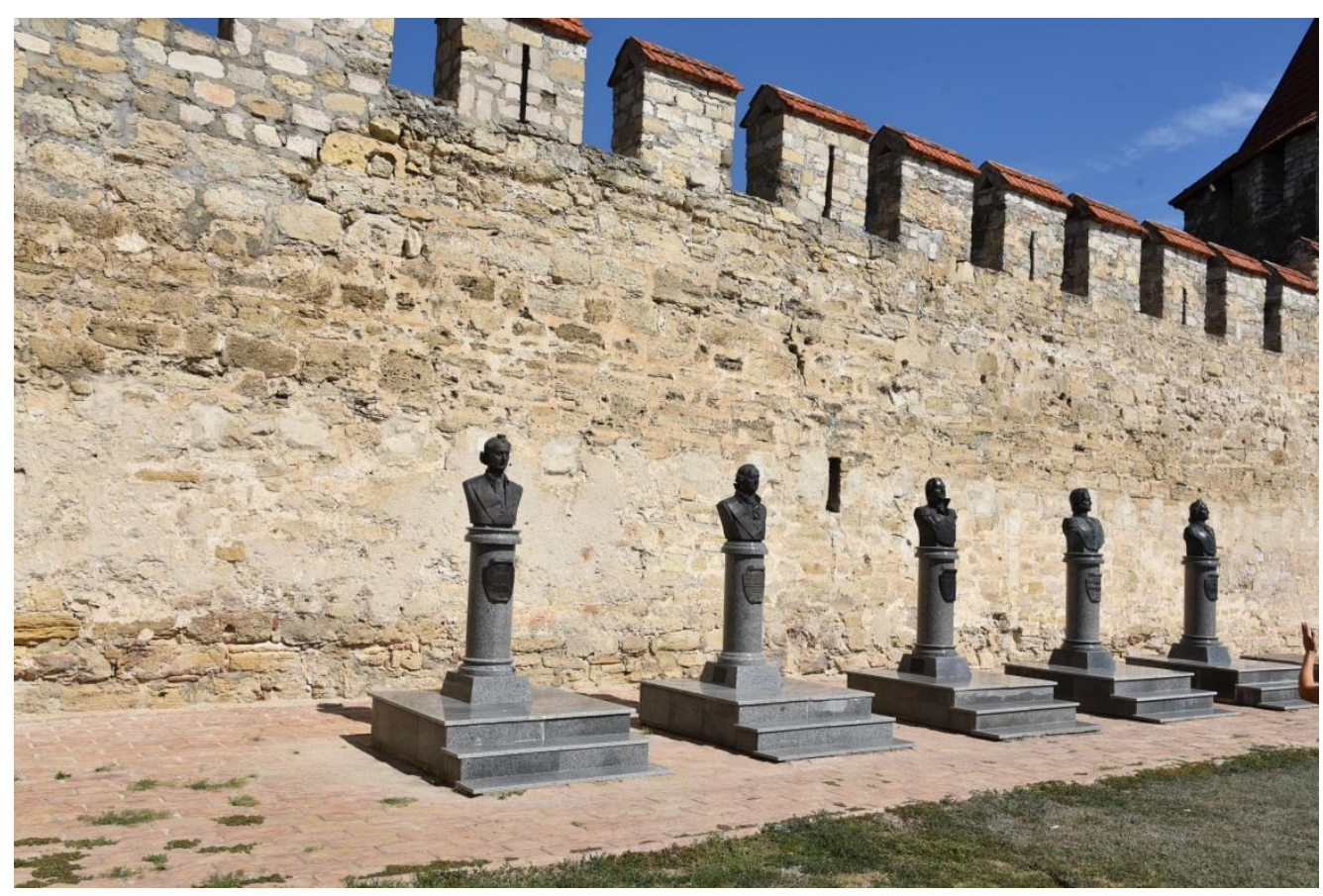

Figure 8. The gallery of Russian officers

(author's own photo, 2019)

We hope that the recent involvement of the EU and UNDP in supporting the rehabilitation of the Tighina-Bender fortress will improve, first of all, the attitude of politicians and stakeholders, secondly of local inhabitants, to the way of approaching conservation and restoration of historic monuments. So, as part of the fifth phase of the European Union Confidence Building Measures Program (EU- CBM V) implemented by the UNDP Moldova, the Italian company Studio Berlucchi SRL has elaborated a report and a series of suggestions regarding the future rehabilitation works of the fortress, which we hope will contribute to the accomplishment of the conservation and restoration works of quality and corresponding to the international standards regarding the protection of the cultural heritage (Figure 9). 


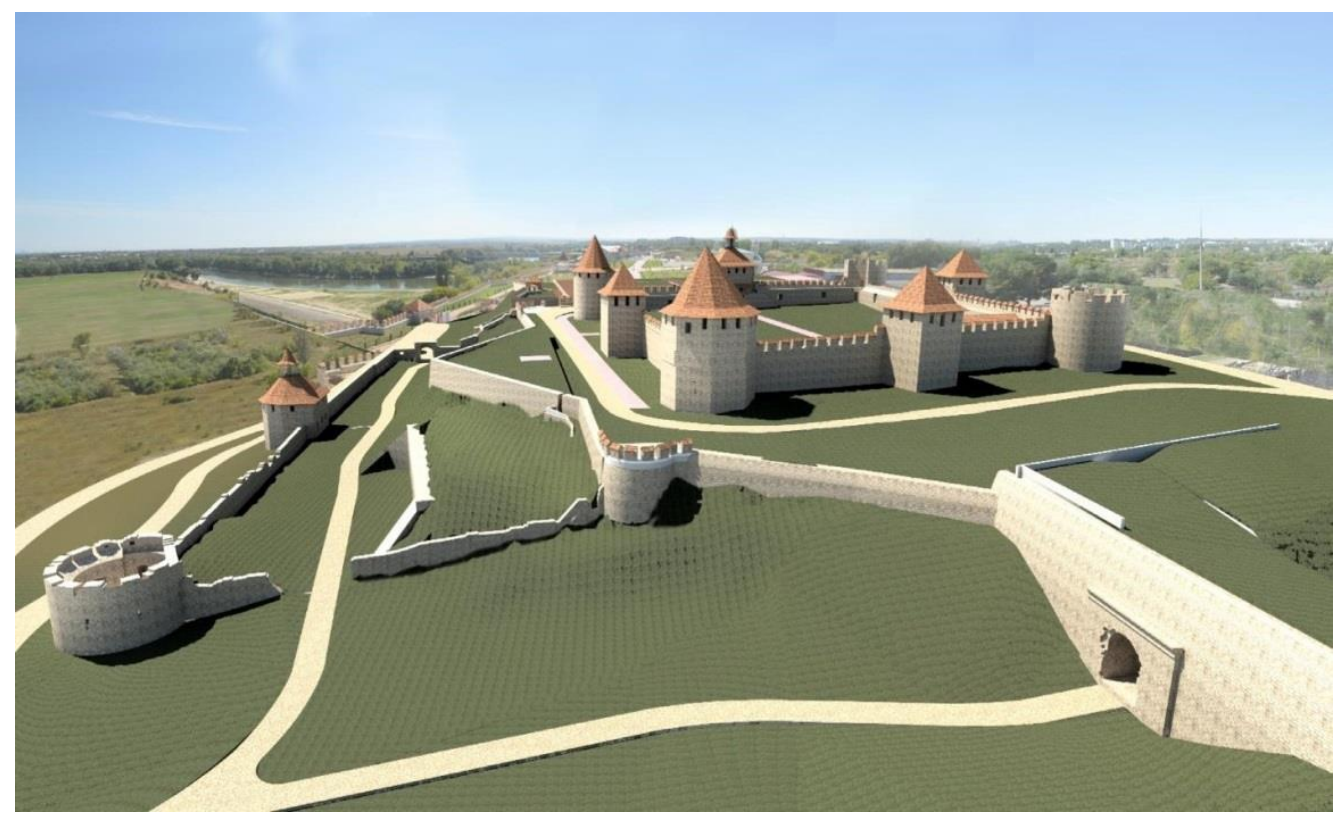

Figure 9. The rehabilitation plan of Tighina-Bender fortress purposed by the Italian company Studio Berlucchi SRL (2019)

We appreciate that the EU also encourages the associated states to develop both the infrastructure for access to historical monuments and their conservation and restoration. We should be grateful to the European Union, but we must also make proper use of European funds in the conservation and restoration of monuments. In this context, we mention the recent document elaborated by the International Council on Monuments and Sites ICOMOS: European Quality Principles for EU-funded Interventions with potential impact upon Cultural Heritage. It states that "all stakeholders involved in cultural heritage conservation should adhere to international cultural heritage charters and guidelines. Cultural assets should be used in respectful ways, to safeguard their meanings and values and to become an inspiration for local and heritage communities and future generations. Recognition of cultural heritage as a common good and responsibility should be a precondition of quality. Cultural heritage conservation should be understood as a long-term investment for society." The State parties should involve their national cultural heritage institutions/administrations from the outset of the programming/negotiating phase and at all stages thereafter and follow adequate principles and standards: project briefs and tenders, design, procurement, implementation, monitoring and evaluation, governance, risk assessments, and mitigation, research, education and training, rewarding quality (https://openarchive.icomos.org/id/eprint/2436/).

I think the steps and objectives established in 2014 by E. Sava's team are still actual and have to be taken into account for future conservation and restoration activities at Tighina-Bender fortress from a complex multidisciplinary perspective:

\section{Steps:}

1. Performing architectural measurements of the structures and exploring the broad perspectives of restoration of the Tighina-Bender Fortress;

2. Conducting the archaeological expertise for the performance of systematic archaeological researches;

3. Conducting historical research to understand the fortress' formation in different historical periods.

4. Creating the Tighina-Bender Fortress Museum and turning it into a national and international tourist destination. 


\section{Objectives:}

1. Prevent the process of continuous decay and destruction of the architectural remains (walls, defense towers, moats and bastions, underground communication channels, and others) by carrying out preservation activities;

2. Perform the restoration of the fortified ensemble applying the latest scientific techniques and methodologies;

3. Museification of the defensive complex of the Tighina-Bender Fortress.

The reconstruction of some parts of the fortress is underway and this method is totally against restoration and conservation (see Figure 10). The work was done by the construction company without any consultation of the experts in the heritage field. The restoration projects should be done by an international team of qualified specialists in various areas of medieval and modern history, archaeology, architecture, and art (Sava et al., 2014).

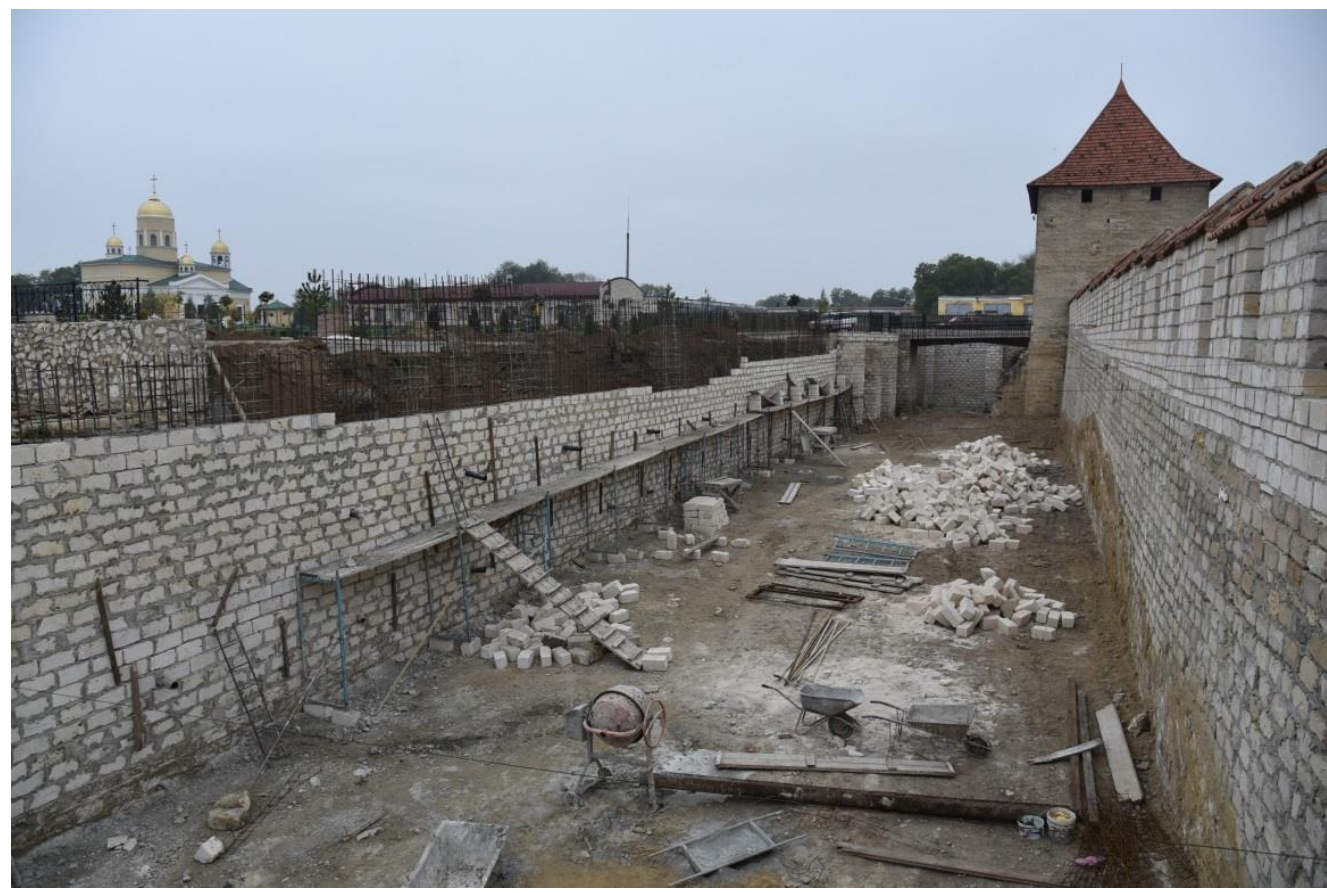

Figure 10. Construction of some parts of the walls around the Tighina-Bender fortress (author's own photo, 2019)

\section{Heritage and cultural tourism. Opportunities for the Bender fortress}

P. Domingo, President of Europa Nostra, pointed very well the role of heritage in the 21st century "Cultural heritage is a capital of irreplaceable cultural, social, environmental and economic value" (Jagodzińska et al., 2015, p. 5). According to recent studies heritage is a key sector in the cultural tourism, which creates more jobs than some other industries or economic areas and has a great contribution to the local, national and global economy.

Opening within a museum complex a store, a hotel, and a restaurant is welcome, and could be an example of a public-private partnership. But this kind of business has to be transparent because it is placed on a historic monument In the specific case of the Bender fortress, the restaurant is quite well designed, planned with a few rooms, each dedicated to a special cuisine (Moldovan, Turkish). Food and drink heritage have been linked to heritage tourism and it is a very important element of the tourism infrastructure (Misiura, 2006, p. 7). 
In the context of the relationship between heritage and tourism, the Tighina-Bender fortress has to remain the greatest and most important part of the museum complex. The exhibitions and guide discourses have to cover objectively all stages of the history of the fortress, events, facts, reflecting diverse people and communities in all ways and do not favorite some historic parts or groups of people depending on political regimes. The museum should be presented in a frame of the local environment, access to the Dniester river, beach, and other facilities which could bring more benefits. That's why is important to have a strategy of heritage and tourism management.

\section{Conclusions}

The Tighina-Bender fortress has a rich history that is limited studied and presented to the public. The recent transformation of the military camp in a museum complex is a step forward for a better understanding of this historic place. We hope that in the context of the current project of Tighina-Bender fortress rehabilitation, due attention will be paid to the complex approach of studying and doing adequate conservation and restoration work, which will complete the history and originality of this site. The museum administration has to have more freedom in the decision-making process, preparing and presenting exhibitions, organizing cultural events, etc. The TighinaBender fortress could become a very attractive brand (Dinnie, 2011; Hultman, YeboahBanin, \& Formaniuk, 2016), if it will adapt to heritage marketing rules and criteria (Zbuchea, 2008, 2014).

Today museums have to resist political challenges and to remain relevant in society. That's why it is the right time to apply the concept „From museum critique to the critical museum" because in the 21st c. museums have to be laboratories of knowledge and democratic community forums (Murawska-Muthesius \& Piotrowski, 2015). Representatives of political parties and the government must grant total independence to museums, as experts are the ones who must decide the museums' policies and strategies. An example of this approach is Sweden, which according to a 2017 law provides the independent position and uniqueness of the museum concerning the level of political decision-making. The law clarifies that policy should not interfere with the content or the perspective of museum activity (exhibition themes, organizational arrangements, patrimony promotion, and museum education, etc.). The law states that the general purpose of museums is to promote knowledge, culture, experience, and freedom of opinion. The museum is perceived as an institution that can and must contribute to sustainable development, social inclusion, and the stimulation of citizens' participation (Gustafsson \& Ijla, 2017).

In the same context the five strategic recommendations from the recent Report Cultural Heritage Counts for Europe should be taken into account: Supporting evidence-based policy-making; Measuring impact; Monitoring trends; Sharing and disseminating data, and Maximizing impact (Jagodzińska et al., 2015, pp. 30-31). The Report points 10 key findings of the cultural heritage too, which are very important for understanding, preservation and using the heritage:

1. Cultural heritage is a key component and contributor to the attractiveness of Europe's regions, cities, towns, and rural areas in terms of private sector inward investment, developing cultural creative quarters, and attracting talents and footloose businesses - thereby enhancing regional competitiveness both within Europe and globally.

2. Cultural heritage provides European countries and regions with a unique identity that creates compelling city narratives providing the basis for effective marketing strategies aimed at developing cultural tourism and attracting investment.

3. Cultural heritage is a significant creator of jobs across Europe, covering a wide range of types of job and skill levels: from conservation-related construction, repair, 
and maintenance through cultural tourism, to small and medium-sized enterprises (SMEs) and start-ups, often in the creative industries.

4. Cultural heritage is an important source of creativity and innovation, generating new ideas and solutions to problems, and creating innovative services - ranging from the digitization of cultural assets to exploiting the cutting-edge virtual reality technologies - with the aim of interpreting historic environments and buildings and making them accessible to citizens and visitors.

5. Cultural heritage has a track record of providing a good return on investment and is a significant generator of tax revenue for public authorities both from the economic activities of heritage-related sectors and indirectly through spillover from heritage-oriented projects leading to further investment.

6. Cultural heritage is a catalyst for sustainable heritage-led regeneration.

7. Cultural heritage is a part of the solution to Europe's climate change challenges, for example through the protection and revitalization of the huge embedded energy in the historic building stock.

8. Cultural heritage contributes to the quality of life, providing character and ambiance to neighborhoods, towns, and regions across Europe and making them popular places to live, work in, and visit - attractive to residents, tourists, and the representatives of creative class alike.

9. Cultural heritage provides an essential stimulus to education and lifelong learning, including a better understanding of history as well as feelings of civic pride and belonging, and fosters cooperation and personal development.

10. Cultural heritage combines many of the above-mentioned positive impacts to build social capital and helps deliver social cohesion in communities across Europe, providing a framework for participation and engagement as well as fostering integration (Jagodzińska et al., 2015, pp. 19-29).

Tiraspol administration has to be more open, to understand that heritage help to build sustainable peace, should try to avoid political influence on interpreting and presenting the past. This approach is perfectly in unison with the Council of the European Union recently approved (June 21, 2021) conclusions welcoming the EU Concept on cultural heritage in conflicts and crises, which enhances the EU's approach to peace, security, and development: "The conclusions recognize that cultural heritage can play a key role in promoting peace, democracy, and sustainable development by fostering tolerance, inter-cultural and inter-faith dialogue and mutual understanding. At the same time, it can also be instrumentalized as a trigger for and target in conflicts. The conclusions call for the protection and safeguard of cultural heritage during periods of conflict and crises." (EU Council, 2021).

The Chişinău Government should be more actively involved, more visible, and with an impact in the management of cultural heritage, especially in the case of the TighinaBender fortress which is a monument of national importance and not to be left to local private and groups of interests, because the cultural heritage belongs to humanity and must be properly capitalized. In this context, the EU, the UN, and other international organizations have to coordinate better all initiatives by involving all interested institutions from both sides.

\section{References}

Anderson, G. (Ed.) (2004). Reinventing the Museum: Historical and Contemporary Perspectives on the Paradigm Shift. AltaMira Press.

Denndorf, R. R. (2019). Refugiul Regelui Suedez Carol Al XII-Lea (1709-1714) în Imperiul Otoman. Calabalâcul de La Varnița [The refuge of the Swedish King Charles XII (1709-1714) in the Ottoman Empire. The Varniţa Calabalâc]. Lexon-Prim.

Dinnie, K. (Ed.) (2011). City Branding. Theory and Cases. Palgrave-Macmillan. 
EU Council (2021). Council approves conclusions recognising the key role of cultural heritage in promoting peace, democracy and sustainable development. https://www.consilium.europa.eu/en/press/pressreleases/2021/06/21/council-approves-conclusions-recognising-the-key-roleof-cultural-heritage-in-promoting-peace-democracy-and-sustainabledevelopment/ (accessed 27.05.2021).

Fero, M. (1981). Use and Abuse of History or How the Past Is Taught. Routledge.

Fortress, Bendery. (2021). 800 Лет Со Дня Рождения Александра Невского - в Бендерской Крепости Прошел Праздничный Концерт [800 Years since the Birth of Alexander Nevsky - a Festive Concert Was Held in the Bendery Fortress]. Bendery fortress web page. https://bendery-fortress.com/en/800let-so-dnya-rozhdeniya-aleksandra-nevskogo---v-benderskoj-kreposti-proshelprazdnichnyj-kontsert (accessed 26.06.2021).

Goliceva, N.V. (1991). Otčet ob Archeologičeskich Issledovanijach Južnogo Učastka Rva Benderskoj Kreposti v 1990 g. [Report on the Archeological Researches from the Southern Sector of the Bender Fortress Ditch in 1990]. Kisinev.

Gonța, Gh. (1998). Cetatea Tighina [Tighina Fortress]. In A. Husar, Gh. Gonța, \& S. Dimitriu-Chicu (Eds.), Cetăţi de Pe Nistru: Hotin. Soroca. Tighina. Cetatea Albă [Fortresses on Dniester: Hotin. Soroca. Tighina. Cetatea Alba] (pp. 104-140), Asociaţia Culturală 'Grai şi Suflet'.

Graham, A., John, G., \& Tunbridge, J. E. (2005). The Uses and Abuses of Heritage. In G. Corsane (Ed.), Heritage, Museums and Galleries: An Introductory Reader (pp. 2637), Routledge.

Gustafsson, C., \& Ijla, A. (2017). Museums - A Catalyst for Sustainable Economic Development in Sweden. International Journal of Innovative Development \& Policy Studies, 5(2), 1-14. http://www.divaportal.org/smash/get/diva2:1096423/FULLTEXT01.pdf

Hâncu, I. (1997). Rezultatele Cercetărilor Arheologice de La Tighina-Bender [Archaeological Research Results from Tighina-Bender]. In Omagiu Lui Vladimir Potlog Și Constantin Drachenberg La 70 de Ani [Tribute to Vladimir Potlog and Constantin Drachenberg at 70 Years Old] (pp. 97-100), Cartdidact.

Hein, H. S. (2000). The Museum in Transition: A Philosophical Perspective. Smithsonian Books.

Hultman, M., Yeboah-Banin, A. A., \& Formaniuk, L. (2016). Demand- and Supply-Side Perspectives of City Branding: A Qualitative Investigation. Journal of Business Research, 69(11), 5153-5157. https://doi.org/10.1016/j.jbusres.2016.04.096

Hynky, I. (1970). K Drevnej Istorii Bender [To the Old History of Bender]. Sovetskaja Moldavija (10 February).

Jagodzińska, K., et al. (2015). Cultural Heritage Counts for Europe: Full Report. Krakow.

Knell, S. (2019). The Contemporary Museum. Routledge.

Koksal, A. H. (2014). Museum as a Transnational Space for National Identities. A Case Study of the Turkish Experience. In A. Meyer \& B. Savoy (Eds.), The Museum Is Open: Towards a Transnational History of Museum 1750-1940 (pp. 233-244), Walter de Gruyter.

Krasnozhon, A.V. (2011). Benderskiy Fortifikatsionnyy Kompleks XVI-XVIII vv. [Bendery Fortification Complex of the 16th-18th Centuries]. Stratum plus, 6, 221-251.

Krasnozhon, A.V. (2018). Фортеці Та Міста. Північно-Західного Причорномор'я (XVXVIII Cm.) [Fortresses and Cities. North-Western Black Sea Coast (15-18 Centuries)]. Видавництво Чорномор'я.

Levinschi, A., \& Sava, E. (2013). 'The Military Camp of Charles XII at Varnița near the Bender Fortress. Tyragetia S.N. VII (XXII)(1), 380-396.

Lipatov, A. (2012). Historia a Polityka Historyczna [History and Historical Plicy]. Herito: dziedzictwo, kultura, współczesność [Heritage, culture \& the present], 8(3), 92113.

Marstine, J. (ed.) (2008). New Museum Theory and Practice: An Introduction. Blackwell Publishing.

Misiura, S. (2006). Heritage Marketing. Elsevier. 
Murawska-Muthesius, K., \& Piotrowski, P. (Eds.) (2015). From Museum Critique to the Critical Museum. Ashgate.

Musteață, S., \& Ciobanu, I. (2021). Raport Știinţific Privind Investigaţiile Arheologice În Cetatea Tighina-Bender. Campania 2019 [Scientific Report on Archaeological Investigations in the Tighina-Bender Fortress. Campaign 2019].

Nesterova, T. (2020). Ob Architekture Zamka Tighina (Bender) [On Architecture of Tighina (Bender) Castle]. Socio-estestvennjaja istorija, 43, 257-263.

Newhouse, V. (2006). Towards a New Museum. The Monacelli Press.

Razumov, S.N. (2019). O Rabotakh Dnestrovskoy Arkheologicheskoy Ekspeditsii Po Issledovaniyu Yugo-Vostochnoy Bashni Tsitadeli Benderskoy Kreposti v 2019 Godu [About the Work of the Transnistrian Archeological Expedition Regarding the Research of the South-Eastern Bastion of T. Tiraspol]. https://benderyfortress.com/o-rabotah-dnestrovskoj-arheologicheskoj-ekspeditsii-poissledovaniyu-yugo-vostochnoj-bashni-tsitadeli-benderskoj-kreposti-v-2019godu?fbclid=IwAR3 NexY2RuvKpysnDe0E182QcQWVWaONPZ0Ez9pSZMU9UwX D8CQINWc903I (accessed 26.06.2021).

Sandell, R. (2007). Museums and the Combating of Social Inequality: roles, responsibilities, resistance. In S. Watson (Ed.), Museums and their communities (pp. 95-113). Routledge.

Sava, E., et al. (2014). Cetatea Benderului. 0 propunere de cercetare și restaurare [Bender Fortress. A Research and Restoration Proposal]. In L. Coadă \& P. Parasca (Eds.), Studii de Arheologie Și Istorie În Onoarea Profesorului Gheorghe Postică [Archeology and History Studies in Honor of Professor Gheorghe Postică] (pp. 184-199), ULIM. http://www.rcchd.icomos.org.ge/?l=E\&m=4$4 \& \mathrm{JID}=4 \& \mathrm{AID}=34 \& \mathrm{l} 2$

Simon, N. (2010). The Participatory Museum, Museum 2.0. http://www.participatorymuseum.org (accessed 25.06.2021).

Șlapac, M. (2004). Cetăţi Medievale din Moldova (Mijlocul Secolului al XIV-lea - Mijlocul Secolului al XVI-lea) [Medieval Fortresses in Moldova (Mid-14th Century - Mid16th Century)]. ARC.

Șlapac, M. (2016). Cetăţile Bastionare din Moldova (Sfârşitul Secolului al XVII-lea - Mijlocul Secolului al XIX-lea) [Bastion Fortresses in Moldova (Late 17th c. - Mid-19th C.)], ARC.

Șlapac, M. (2020). Castelologia Comparată. Arhitectura de Apărare a Ţării Moldovei Între Occident și Orient [Comparative Castellology. The Defense Architecture of Moldova between West and East], ARC.

Tentiuc, I., Levinschi, A., \& Sava, E. (2017). Investigațiile istorico-arheologice ale sitului istoric „Tabăra regelui Suediei Carol al XII-lea de la Varnița” [Historicalarchaeological investigations of the historical site "Camp of King Charles XII of Sweden in Varnița"]. In E. Sava, \& E. Ploșniță (Eds.), Situl istoric Tabăra regelui Suediei Carol al XII-lea de la Varniț. Restaurarea memoriei [Historic site the Camp of King Charles XII of Sweden in Varnița. Memory restoration]. Biblioteca Tyragetia, XXIX (pp. 123-152), The National History Museum of Moldova.

Wittlin, A. (2004). A Twelve Point Program for Museum Renewal. In G. Anderson (Ed.), Reinventing the Museum: Historical and Contemporary Perspectives on the Paradigm Shift (pp. 44-60), AltaMira Press.

Zbuchea, A. (2008). Marketingul în Slujba Patrimoniului [Marketing serving the heritage]. Editura Universitară.

Zbuchea, A. (2015). Marketing Muzeal pentru Nonmarketeri [Museum Marketing for Nonmarketers]. Tritonic.

Zbuchea, A., Romanelli, M., \& Bira, M. (2021). Through the public's Lens: Are museums active members of society? An investigation during the COVID-19 pandemic. In P. Demartini, L. Marchegiani, M. Marchiori, \& G. Schiuma (Eds.), Cultural Initiatives for Sustainable Development: Management, Participation and Entrepreneurship in the Cultural and Creative Sector (pp. 61-94), Springer. https://doi.org/10.1007/978-3-030-65687-4 
Culture. Society. Economy. Politics | 39

Vol.1 (2021) no.1, pp.21-39; DOI 10.2478/csep-2021-0003

Received: March 21, 2021

Accepted: May 25, 2021

\title{
Acknowledgments
}

This study was developed within the Project "Research and capitalization of medieval archaeological heritage in the Republic of Moldova - CVPAM", number 20.80009.1606.06, implemented by the "Ion Creanga" State Pedagogical University in Chișinău, supported by the National Agency for Research and Development of the Republic of Moldova through the State Programs 2020-2023, strategic priority IV. Societal challenges, strategic direction Tangible and intangible heritage.

\begin{abstract}
Author biography
MUSTEAȚĂ Sergiu is currently Associate Professor at the History and Geography Department, 'Ion Creangă' State Pedagogical University of Chișinău, Republic of Moldova. He is the author of 8 monographs and more than 300 articles on history, archaeology, cultural heritage preservation and textbooks analysis. The most recent works on heritage issues are Managementul patrimoniului mondial: de la situația din România la exemple de bune practice [World heritage management: from the situation in Romania to examples of good practice], Chișinău - Cluj-Napoca, ARC \& MEGA Publishing Houses, 2020; "The State of Conservation and Periodic Reporting - A Way for Better Preservation and Sustainable Development of the World Heritage Sites". In Plural. History. Culture. Society, vol. 8. No. 1, 2020, 227-242; "Community Archaeology in Eastern Europe. An Example from the Republic of Moldova". In Jameson, John H. and Sergiu Musteata (eds.), Transforming Heritage Practice in the 21st Century - Contributions from Community Archaeology. One World Archaeology Series. Springer, 2019, pp. 45-58; "Archaeological Heritage Resource Management in Romania and the Republic of Moldova: A Comparative View". In S. Campbell, L. White, \& S. Thomas (eds.) Competing Values in Archaeological Heritage. Springer, Cham, 2019, pp. 45-61; Nomads and Natives beyond the Danube and the Black Sea, 700-900 CE, Amsterdam University Press, ARC Humanities Press, Leeds, 2018. He is the editor of two monograph series - ANTIM monographs and Unknown Documents and Histories (30 volumes published). Every year he delivers over 20 presentations and public lectures in various academic centres around the world. During recent years, he has been a visiting scholar and a visiting professor in many universities in the USA, Germany, Poland, Romania, Sweden, etc.
\end{abstract}

(C) 2021 Faculty of Management (SNSPA), Author(s). This is an open-access article licensed under the Creative Commons Attribution-NonCommercial-NoDerivs License (http://creativecommons.org/licenses/by-ncnd/4.0/). 